\title{
OTTER RESEARCH
}

\section{By Marie Stephens}

In Oryx, Vol. 2, No. 3, there was a brief account of the Otter Committee and how and why it was formed. There are many problems which it has been endeavouring to solve, particularly in connection with the otters' breeding and feeding habits. One important question is whether this delightful animal is a menace to fishing and in need of control, as some people believe, or whether in fact it is a harmless, beneficial creature, which deserves peace and protection from mankind.

I was appointed as full-time research worker to the Committee in October, 1952, on a two-year grant from the Nature Conservancy, and was kindly offered laboratory facilities at the London Zoo. It is here that the greater part of my work is carried out, under the direction of Dr. Harrison Matthews.

Although otters are more numerous in this country than is generally realized (otter hunters estimate that they average about one per 5-7 miles of river in most parts of England and Wales) they are shy, nocturnal animals and are rarely seen except during hunts or by an occasional fisherman in the evening or early morning. They are solitary creatures and great wanderers, covering many miles in a night, and they do not often use the same "holt", or sleeping place, for many days in succession, except when a bitch otter is nursing her cubs. All these things make them even more difficult to watch and study in the field than most other British mammals. Problems involved in live-trapping and handling large numbers of otters make markingand-release methods, such as those used for rabbits and small rodents, quite impracticable.

There is one way in which otters help the investigator, however, and that is by having such incomplete digestive powers! Fur, feathers and small bones pass through their intestines practically untouched, and because of this it is possible to get some idea of their diet by examining their fæces or "spraints". Similarly, one can learn something of their feeding habits by analysing the stomach and intestinal contents of dead animals. Dead otters are also useful for studying anatomy, reproduction, parasites, bone development, histology and so on.

One of my first jobs was to contact as many people as possible in all parts of Britain who might be able to help me by giving information about the distribution and habits of otters, or by sending in spccimens of spraint from different localities. These contacts include masters of otter-hounds, river and fishery board 


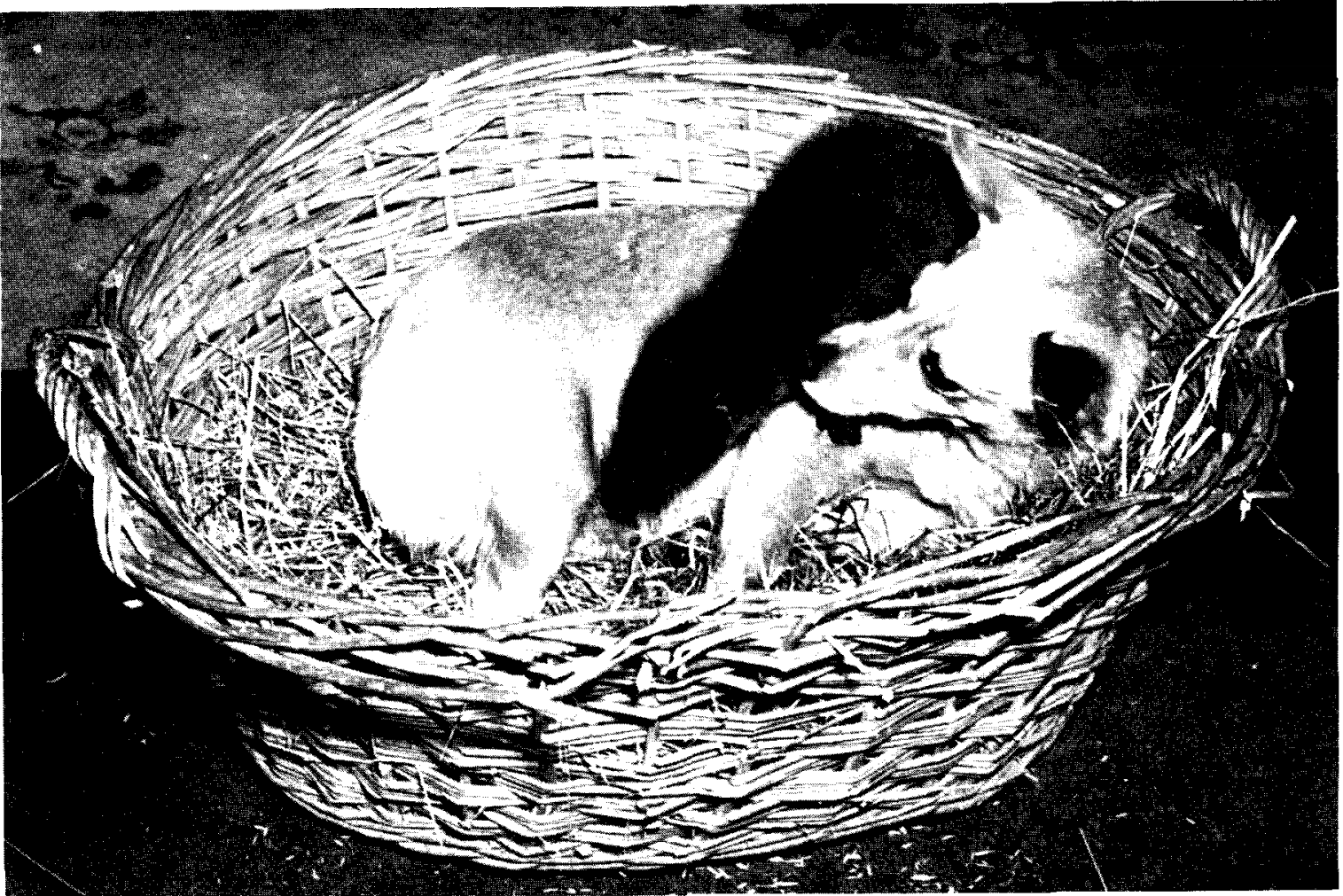

BIBY oTTLR WITH FOSTER-MOTHER 
officials, managers of fish hatcheries, pest officers, private keepers and water-bailiffs and numerous individuals. Most of them have been very helpful, even if all have not been able to give me much practical assistance, and new contacts have been made all the time.

Carcases present a more difficult problem as a large and regular supply throughout the year would be needed before any reliable information about the breeding cycle could be obtained. We know that a great many otters are killed each year by trapping or shooting, besides an occasional one being run over by a car, but the problem is how to get hold of them without encouraging people to trap otters especially for us. It was decided that five shillings would be a fair price to offer per body, as it is not enough to encourage extra trapping and yet should make it worth while for the regular trapper to send in his catch. Pelts, which fetch up to $£ 3$ on the market, are not necessary for the investigation. Hunted otters are never sent in, as they are the hounds' " reward" after each kill, but at the few hunts I have attended I have been allowed to inspect the bodies on the spot, before they were thrown to the hounds. Naturally, an otter can play havoc if it gets into a breeding pond, and the majority of those received have been trapped at fish hatcheries. The total number in twenty months has been only forty-five, with a majority of dog otters and not nearly enough for any detailed reproductive study.

I was kindly allowed to use preserved material from the Zoo's prosectorium for a preliminary study of anatomy, and at the outset the otters in the Gardens were made available to me for live experiments. Before long, however, we received two young cubs from the Severn Wildfowl Trust, and these have been used for studying growth-rates, etc., for filming, and for various controlled feeding tests. They are now well over a year old and I am hoping, rather optimistically perhaps, that some time it may be possible to breed from them.

Another very young orphaned cub was sent to the Zoo after being rescued from a flooded river in Cumberland last January. It was adopted by my corgi bitch, Meg, and they were very happy together for some time until the baby otter suddenly died of pneumonia. Meg was heartbroken and looked for him for days afterwards !

Otters are the subject of little scientific work, but nevertheless they are mentioned quite frequently in literature and several useful semi-scientific books and articles have been written about them. A large and comprehensive " otter literature " card index 
has been compiled. I have also contacted workers studying the animal in the United States and in Switzerland, and have been given access to evidence collected by both the Government's Committee on Cruelty to Wild Animals and by the Ministry of Agriculture and Fisheries.

Various "ottery" rivers and streams have been visited at different times in Essex, Shropshire and many parts of Wales. It has not been possible to visit the North of England or Scotland yet, although there are probably more otters in Scotland than anywhere else in the British Isles. Along parts of the Scottish coast they have adopted an almost entirely marine life.

I spent some time in Shropshire last June making a short but intensive study of a stretch of the Camlad, a tributary of the River Severn. Here otters breed regularly each year. Unfortunately I was too late for last season's cubs, but nevertheless my stretch of stream was frequented by otters regularly. It was very rarely that they could be seen, even if one sat for hours watching for them through the long summer nights, but each morning it was obvious that they had been there by the new evidence left behind. "Seals," or pad-marks, are not commonly found along rocky streams such as the Camlad, but the presence of fresh spraint is a sure sign that an otter has been that way. They have regular stopping places, generally on a shingle beach or at a suitable "lie-up " under an overhanging root, a rock midstream, a holt entrance, or a grassy jut of bank; occasionally spraint can also be found on a track some distance from the water. I collected a large number of spraints from this area and the farmer at whose house I stayed sends me fresh samples periodically, so that I can build up a picture of the food changes of otters throughout the year in that particular locality.

By the middle of July, 1953, most of the ground-work had been done, some live experiments completed, specimens were coming in-irregularly-from all parts, and the laboratory work seemed to be well under way. I felt that now was the time to go out and find a suitable spot for starting some longer-term field studies. Fortunately a fellow-worker in the prosectorium offered to cope with any specimens arriving at the Zoo during my absence and the live cubs were in the capable hands of the sanatorium staff. I set off for Cardiganshire, and there I was allowed to make the Department of Animal Health at Aberystwyth my temporary headquarters.

Some time was spent in examining the West Wales rivers, and $I$ made many very helpful and interesting contacts among the water-bailiffs and keepers. 
The River Teifi holds numerous otters, which are often seen at night by the local fishermen. It is a beautiful river, with many regularly used holts where one can be almost sure to find an otter at home. It is too wide and deep for wading and for examining in detail however, and I eventually decided to concentrate my attention on the Clettwr, a tributary entering the Teifi just above Llandyssul.

The stretch I chose lies just below Pontshaên, where the Clettwr Fach joins the Clettwr Fawr, and covers approximately 3 miles of fast-moving stream. About half of this runs through the Alltyrodyn estate, which is a perfect sanctuary for otters. There are several good holts, some in hollow tree roots, some in earthy burrows in the banks; tracks indicate that otters sometimes sleep out in the reeds away from the water. A suitable tree overlooking a weirpool seems to be a favourite choice for establishing a holt.

I plotted day-to-day findings on large-scale maps and learnt much of the movements of the otters on this stretch of river. I collected many spraints, and when October came found that the number began to increase enormously. No doubt the otters were making their way up side-streams from the main river in readiness for the spawning scason in carly November.

Unfortunately I had to leave the Clettwr in mid-October, but possibly some longer-term otter research can be undertaken later. By then we should have worked out some more exacting field experiments.

It would be interesting to watch a holt with cubs. Otters breed at any season of the year and the cubs, which are born blind, live with their mother for many months. There may be up to five cubs in a litter, but two or three is the most usual number. During the weeks they are being suckled, and later taught to swim and catch fish, they remain in the same nest. At first they have a natural aversion to water and have to be forced into it. Father takes no part at all in their upbringing. By watching a young family of this kind much could be learnt of the otter's ways.

Now that the two-year investigation is nearly up I am busy analysing the remaining spraint samples and working out the final results. The spraints are first examined for parasites by the Zoo's histologist and then the food contents are identified by direct comparison with a collection of skeletons I have prepared.

The diet varies widely and includes many small mammals and birds (mostly moorhens), besides crayfish, frogs, and fish. Eels figure prominently and also coarse fish, besides large numbers of Salmonidae. So otters appear to do both harm and good to 
fishing, on the one hand by killing some valuable fish and on the other by clearing the streams of many predators of salmon and trout spawn and fry. I cannot quote any figures at this stage, but it is doubtful if they are responsible for half the damage of which they are sometimes accused.

The above briefly covers my research during the past twenty months. Any readers interested in watching otters themselves would be advised to choose a quiet, unfrequented spot and, above all, to have unending patience! Fresh seals and spraints are signs that otters are about and, in snowy weather, their seals and slides can sometimes be traced for long distances in the snow. A convenient holt is quite easily found, but there is no guarantee that it will be inhabited on the night you choose to make your observations! 